\title{
Complexity of Unsolved Forest Tenurial Conflict: A Case of Way Terusan Forest Management Unit, Lampung Province, Indonesia
}

\author{
Christine Wulandari ${ }^{* *}$, Yulia Rahma Fitriana ${ }^{2}$, Indra Gumay Febryano ${ }^{2}$, Susni Herwanti ${ }^{2}$, Hari Kaskoyo ${ }^{2}$, \\ Hendika Jaya Putra ${ }^{3}$
}

${ }^{1}$ Graduate Program of Forestry, the University of Lampung. Jl. S. Brojonegoro 1, Bandar Lampung, Lampung, Indonesia 35145

${ }^{2}$ Forestry Department, Faculty of Agriculture, the University of Lampung, J1. S. Brojonegoro 1, Bandar Lampung, Lampung, Indonesia 35145

${ }^{3}$ Way Terusan Forest Management Unit, Forestry Lampung Provincial Office, Central Lampung District, Lampung, Indonesia 35145

Received May 11, 2021/Accepted October 26, 2021

\begin{abstract}
Effective forest management is challenging to achieve when there is uncertainty about who controls forest areas. Land tenure issues can arise from local communities, immigrants, the private sector, or the government. Overlapping rights in forest areas are very likely to occur due to the licensing system's lack of integration and the inaccuracy with which the problem of forest land use claims. The Forest area of Register 47 is the case where the forest tenurial conflict resolution is theoretical and takes into account the existence of forest communities and conflict resolution programs that have been implemented by the Forest Management Unit (FMU). This study employed case study approach carried out with an in-depth study in the historical study about the conflicts and juridical review in Way Terusan FMU, Lampung Province. The collected data was then validated by triangulating scheme by the observation and documentation. The findings show that in terms of legal, FMU is the legal authority in forest area organizations, especially after regional regulation since 2019. However, the encroachment began in the 1990s when about 900 households were relocated to the area without the Forestry Ministry accord. Various legalization permits were submitted to the central government, but they were not deemed as a viable option. Since the regional regulation of forest area law's introduction in 2019, the FMU has been the primary actor in forest management. In order to resolve all conflicts, the FMU might apply for some effective forestry partnership cooperation programs.
\end{abstract}

Keywords: encroachment, unsolved tenurial conflict, forestry partnership, local community

*Correspondence author,email: christine.wulandari@fp.unila.ac.id

\section{Introduction}

The effectiveness of forest management will be challenging to achieve if there is uncertainty in forest areas' control (Simmons et al., 2018, McLain et al., 2021, Schürmann et al., 2020). Problems that arise in the field resulting in uncertainty over land tenure can come from local communities, immigrants, the private sector, or the government (Wario et al., 2012; Simmons et al., 2018; Jenke $\&$ Pretzsch, 2021). The occurrence of overlapping rights in forest areas is very likely to occur because of the lack of integration of the licensing system and the inaccurate resolution in describing the problem of forest land use claims (Stickler et al., 2017; Gebara, 2018; Tjoa et al., 2018; Jun et al., 2020; Yiwen et al., 2020). According to Galudra et al. (2014), Sylviani \& Hakim (2014), and Purnomo and Anand (2014), land ownership tenure conflicts occur because of differences in perceptions and interpretations of stakeholders towards land and forest resources. The differences arise because the stakeholders do not clear understand of community rights or regulations concerning forest areas they manage.

Illegal logging, land degradation, forest revenue, community development, and forestry expansion are primary challengers in Indonesian forest development (Handoko, 2014). Some of the conflicts in forest management are tenurial conflicts (Katila et al., 2020). According to Larson (2013), Sahide et al. (2017), and FAO (2019), forest land tenure relates to who owns, uses, manages forest land, and decides forest resources. Therefore, it is necessary to have a site-level management unit that will directly provide understanding to the community to resolve the tenurial conflict. Its site-level management unit is known as Forest Management Unit or FMU.

The FMU at the site level for conflict resolution is essential based on the consideration FMUs are expected to play a strategic role in conflict resolution in Indonesia. Each FMU is built based on specific local conditions, therefore FMU can accommodate the interests of the surrounding 
community quickly and respond positively to all inspirations from local relevant parties (Working Group Tenure, 2012; Kim et al., 2016; Massiri et al., 2020).

In Indonesia, as of May 3, 2021, the Ministry of Environment and Forestry (MoEF) identified that there are 446 tenurial forest conflicts (MoEF, 2021). One of the FMUs with many complicated conflicts is Way Terusan ${ }^{1}$ FMU. The local community is very dependent on the forest, and they use the forest in an unsustainable way. Syaifullah and Sarjono (2012) also reported that this FMU have continued as same unit of management since 2001. The causes of forest conflicts in Way Terusan's FMU have differentiated from other FMU and can be classified into two: 1) overlapping land boundaries with state forests, private sectors and/or customary lands, and 2 ) the interests of individuals, political figures, or institutional elements. Others FMU generally has land boundaries conflict with state forests only. In contrast, it is found that more than $70 \%$ of the land in the Register 47 forest area has been used by local communities, both immigrants and residents (Syaifullah \& Sarjono, 2012). Unfortunately, the management of the communities' existence in the forest area has not been fully and accurately accommodated in the 2014-2024 Rencana Pengelolaan Hutan Jangka Panjang (RPHJP $^{2}$ ) of Way Terusan FMU. Previous studies related to recommendations for conflict solutions in Register 47 forests are still very few and remain unsolved.

Based on these conditions, Register 47 is an appropriate case study to explore some recommendations for forest tenurial conflict solutions. Register 47 area have the existence of communities living in forests and conflict resolution programs that have been and are being implemented by the main actors in the region (the Way Terusan FMU). Usually, research on forest tenurial conflicts discusses the actors and typologies of various conflicts that occur (including traditional land-use conflicts) and then gives various recommendations for tenure conflict resolution based on theory. However, van Aken (2014) mentioned conflict resolution recommendations based on theory are sometimes not necessarily applicable in the field. Thus, recommendations for forest tenurial conflict resolution under conditions in the field, following community dynamics, and forestry development programs carried out by authorities over forest management will better ensure conflict resolution programs' success in a given location (van Aken, 2014). Therefore, the objectives of this research are as follows: 1) to study the development of the utilization of the area as well as the institutional Way Terusan FMU, 2) to identify and analyze the development of conflict resolution occurring in Way Terusan FMU until March 2021.

\section{Methods}

The field data collection was conducted from January to March 2021 at Way Terusan FMU (Figure 1). This study employed a grass-root approach using a qualitative paradigm combined with quantitative data (Sugiono, 2012;

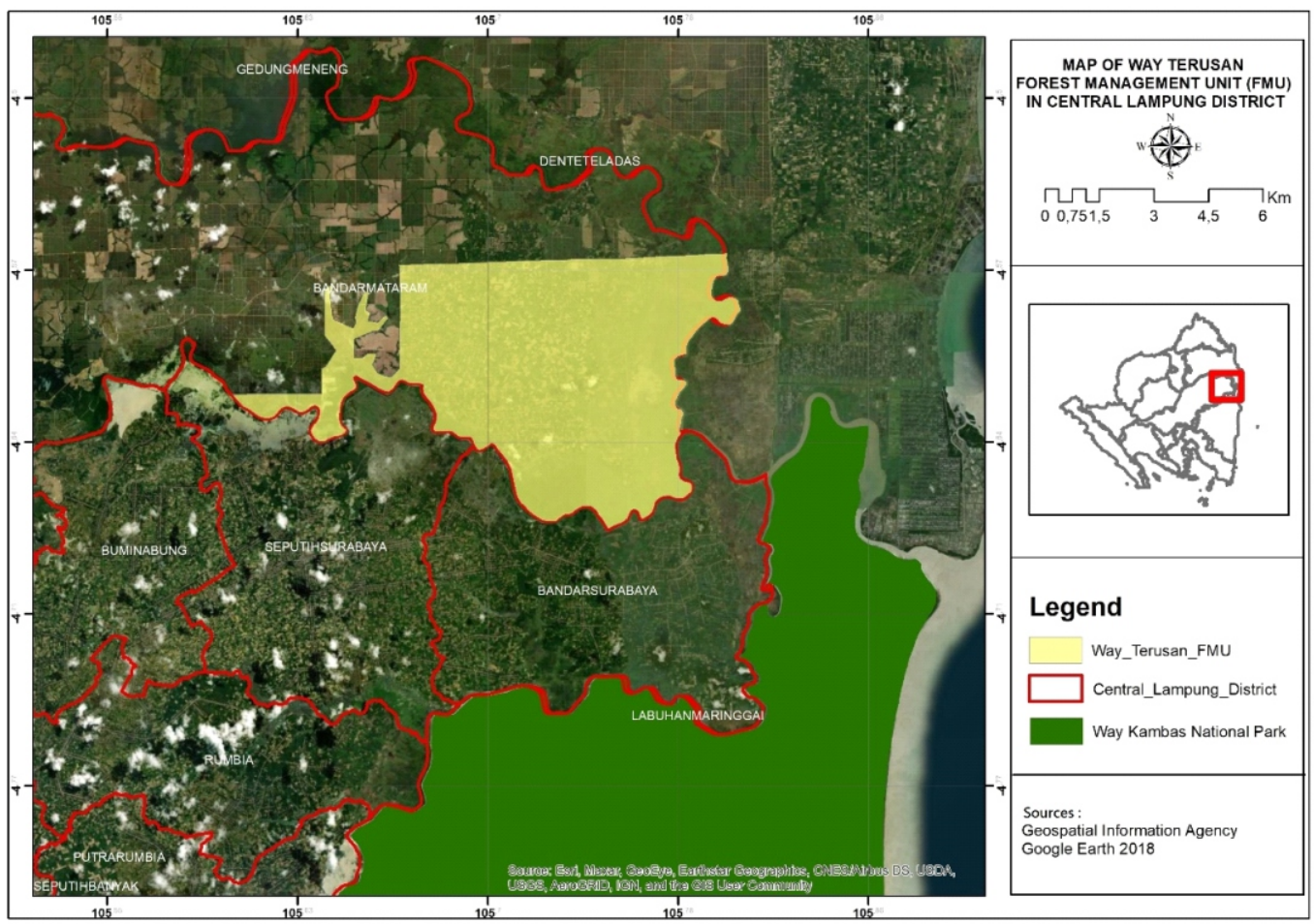

Figure 1 Map of Way Terusan Forest Management Unit.

The Forest Management Unit is Way Terusan, whilst its area of the forest is called "Register 47". The forest area of Register 47 is classified as permanent production forest based on government classification.

Rencana Pengelolaan Hutan Jangka Panjang or RPJHP equivalent to Long Term Forest Management Planning document for 20 years. It is prepared by each FMU. 
Tashakkori, 2021). This method is appropriate to a case study approach (Yin, 2014). According to Yin (2014), it comprises various data collection techniques, namely field observations, interviews with key informants, historical tracing, and forest management community surveys.

For data analysis, the first analysiswas to classify the type of forest tenurial conflict that occurs. And then, the second analysis was to determine the alternatives solutions for those tenurial conflicts, using 1) a technical approach to the historical sequence of land ownership and forest conflict and 2) a formal juridical approach under the prevailing laws and regulations.

Historical sequence techniques were in the form of activities to re-reveal the community's history in a particular location by describing important events in the past, either based on existing literature or direct information from the community (Senoaji et al., 2019). Whilst the juridical approach was carried out by examining all laws and regulations relating to legal issues and problems being handled (Zaini, 2011).

Determining the respondents for historical forest conflict in Way Terusan Unit required for more in-depth research was carried out using the snowball sampling technique to identify the involved respondents in the study area, that is, by following the previous respondent's information to determine the next respondent (Sugiono, 2012; Tashakkori, 2021). For this research, the respondents are the related stakeholders that can be classified as: 1) representative of 13 Forest Farmer Groups in Register 47 area, 2) district government through the department of transmigration and district's chief official, 3) representatives of three villages and customary representatives, 4) representatives of subdistrict, and 5) representatives of Way Terusan FMU. The $\mathrm{RaTA}^{3}$ framework was used (Galudra et al., 2010), which focused on respondents analysis. The respondents analysis in RaTA was used to understand how community influences policies and institutions and how policies and institutions affect them (Galudra et al., 2020). The total respondents are 54 persons, i.e. 39 persons as representatives of 13 forest farmer group, 3 persons from transmigration department, 6 persons representatives of 3 villages, 3 persons from subdistrict government, and 3 persons as representative of Way Terusan FMU.

Data validation from respondents were carried out by triangulating sources and techniques. Source triangulation was made by checking data on other data sources from different respondents' classification. Interview carried out technique triangulation, then checked by observation and documentation (Sugiono, 2012; Wilson, 2014).

The next step was to detect the disputing style by implementing the assessment method called analisis gaya besengketa/AGATA of the actors or communities in research location in responding to conflicts. Pasya and Sirait (2011) developed AGATA to map the attitudes of conflict actors in dealing with disputes Pasya and Sirait (2011) categorized the attitudes into 5 types.

1) Avoiding style occurs when one party rejects the existence of a dispute, changes the topic of the cause of the dispute to another topic that is not the cause of the

\footnotetext{
RaTA is a a manual to identify the nature of land tenure conflict.
}

dispute, avoids discussion about disputes, behaves in a noncommittal manner, or does not want to build a commitment. This style is especially effective in situations where there is a danger of physical violence, no opportunity to achieve a goal, or a situation that is so complex that it is impossible to resolve it.

2) Accommodating style occurs when one party sacrifices individual/group interests and puts the other party's interests first. This style is effective when a party realizes that they do not have many opportunities to achieve their interests or when there is a belief that satisfying individual/group interests will damage their relationships with other groups. Accommodating is defined as accommodating the other person's requests or demands (Huan \& Yazdanifard, 2012).

3) Compromising style occurs when each party acts together to take the middle ground, for example, by giving to each other, and in this action, it is not clear who wins or loses. This style is effective in situations where the parties refuse to cooperate while at the same time a way out is needed and when the goal is not an important part. However, in this style, true satisfaction is usually not achieved. The compromise-style party facilitation means resolving conflict by negotiating a fair and equitable division (Huan \& Yazdanifard, 2012).

4) Competing style is a dispute style characterized by aggressive actions, selfishness, pressure on others, and uncooperative behavior. This style is effective when decisions must be made immediately. The number of decision choices is very limited or even only one, one party does not feel the loss even by pressing the other party, and most importantly, there is no concern about the potential damage to relationships and social order.

5) Collaborating style is characterized by active listening to each party's interests, focused concern, empathetic communication, and mutual satisfaction. This style is effective when there is a power balance, besides sufficient time and energy available to create an integrated dispute resolution.

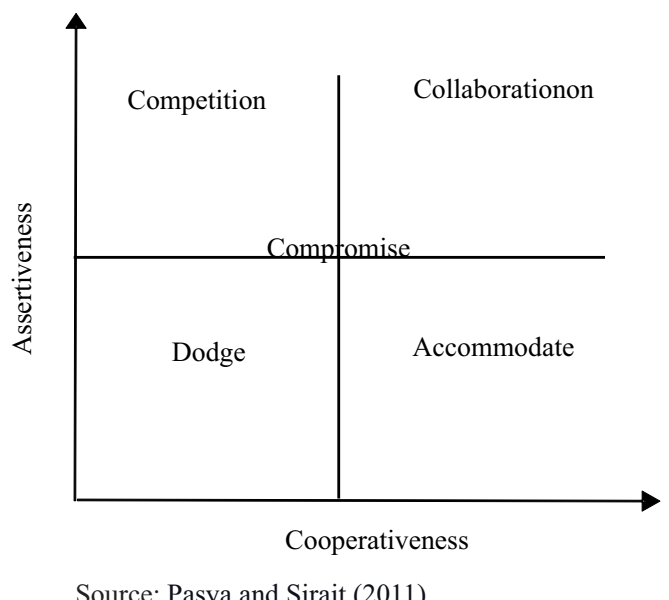

Figure 2 Combination of conflict handling through cooperativeness and assertiveness. 
Conflict handling style is formed from two elements: cooperativeness and assertiveness. Cooperativeness is an attempt to satisfy the other party when faced with a conflict. On the other hand, assertiveness is an attempt to satisfy oneself when faced with conflict. The combination of these two elements is the cross-axis quoted from Pasya and Sirait (2011), as shown in Figure 2.

The difference in this study regarding the conflict style analysis from the previous studies (Figure 2) is because the conflicting parties' styles are mapped in the cross-axis model (Gamin et al., 2014), which is then used as a basis for taking conflict resolution actions. Previous studies have no compromise way in the cross-axis model as a forest conflict solution.

\section{Results and Discussion}

History of forest management unit establishment and recent status The FMU development aims to restructure all production and protected forests and conservation areas into management units according to site types to ensure the sustainability of rational and profitable businesses. Besides, it aims to provide forest products and other benefits for national development, regional development, and forest communities sustainably. Based on the Minister of Forestry Regulation Number P.6/Menhut-II/2009 concerning Establishment of FMU Areas, article 1 point 8, an FMU area design that contains the results of the initial identification and delineation of the area to be formed into an FMU area in the map and its description.

The FMU area is established through the following stages (the Minister of Forestry Regulation Number P.6/2009 article 7): FMU design; FMU reserve directions; proposal for establishing FMUs; and determination of FMU areas. The Register 47 FMU area, Way Terusan $( \pm 12,500 \mathrm{ha})$, based on the Decree of the Minister of Forestry Number SK.316/Menhut-II/2005, dated August 25, 2005, this forest area, which belongs to the Way Terusan Forest group of Central Lampung District, Lampung Province, is a Production Forest Management Unit (FMU). It has been followed up by: 1) the Letter of the Governor of Lampung Number 061/3125/02/2006, concerning the Establishment of the Production Forest Management Unit (FMU) Organization Reg. 47 Way Terusan, 2) the District Regulation of Central Lampung Number 10/2008 concerning the establishment of the organization and work procedures for the technical implementation unit (Unit Pelaksana Teknis Daerah/UPTD) of the Production Forest Management Unit of Way Terusan, Central Lampung District.

The main task of the UPTD is to prepare plans for management, maintenance, planting, processing, marketing of forest products, replanting forest areas, which is carrying out its duties is responsible to the Head of the Forestry Service and is operationally coordinated with the Heads of the Sub-Districts in its area. Figure 3 shows the organizational structure of UPTD-FMU Reg. 47 Way Terusan according to the District Regulation of Central Lampung Number 10/2008.

Based on Law Number 23/2014 concerning regional government, in Article 14, forestry affairs are divided only between the central government and the provincial government. According to this law, regencies/cities no longer have the authority in terms of forest management, except for grand forest parks. This policy came into effect in 2016. Then it was followed up by the Lampung Provincial

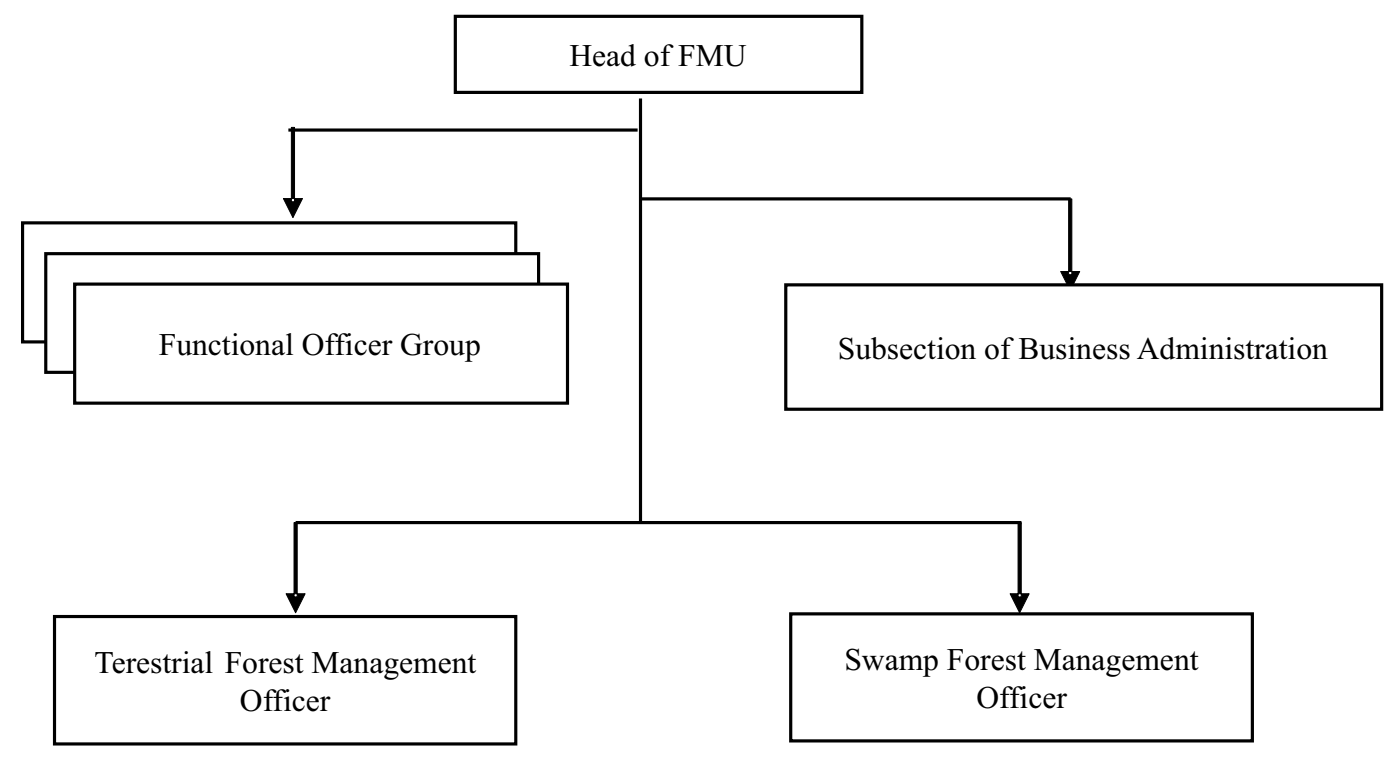

Source: Way Terusan FMU (2021)

Figure 3 Organizational structure of Way Terusan FMU based on District Regulation of Central Lampung Number 10/2008. 


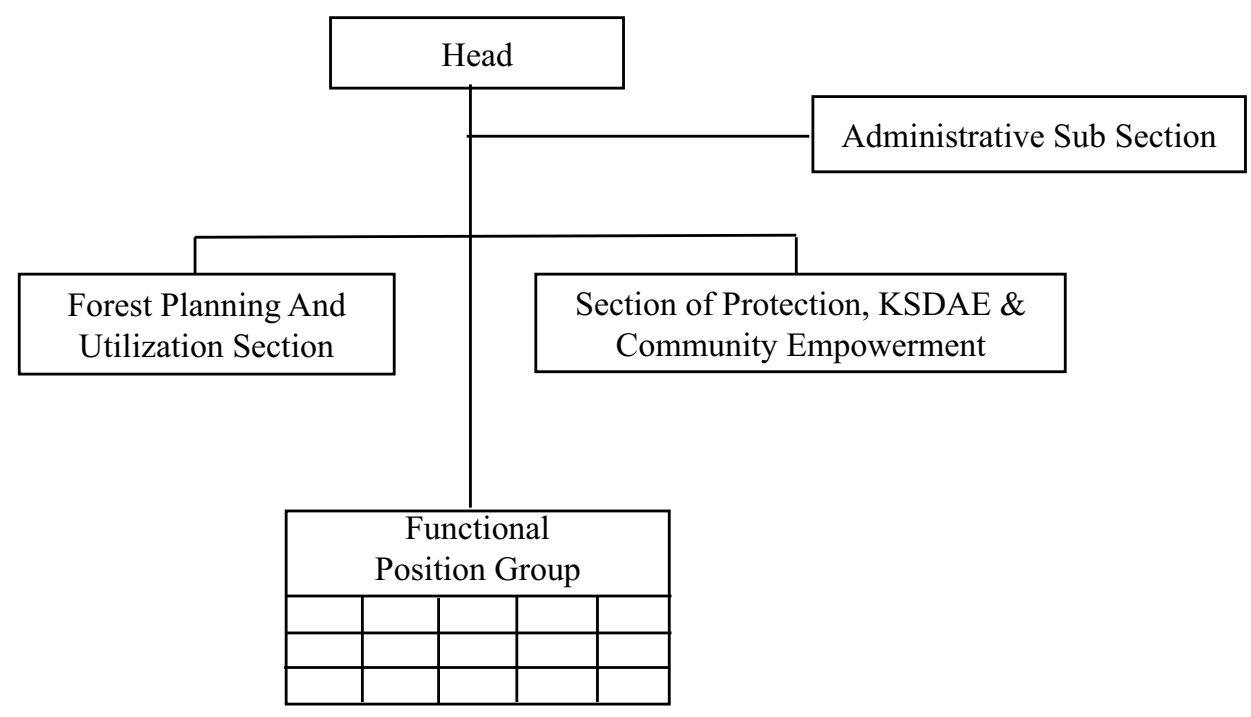

Source: Way Terusan FMU (2021)

Figure 4 Organizational structure of Way Terusan FMU based on Regulation of Lampung Governor year 2019.

Regulation Number 4/2019. Figure 4 shows the organizational Way Terusan FMU based on the 2019 Regional Regulation.

Compared with the FMU organizational structure before Law 23/2014 on regional government, the FMU organizational structure is more effective and efficient in the field now. It is because the function of FMUs as operators at the site level is running as it should. The current FMU organization is more focused on FMU organizational and personnel affairs, planning (area management and community services)., operational, technical affairs (protection, services, and community empowerment) FMU heads manage FMU based on their authority. They can divide the work area into resort units headed by a resort head so that any work and problem-solving in the field can be more focused under the resort's working area.

Development of utilization of forest area and the initiation of conflict The development of the forest usage is shown in Table 1. In the beginning, the designation of the Way Terusan permanent production forest area (Register 47) is based on the Minister of Forestry of the Republic of Indonesia's Decree Number SK.930/Menhut-II /2013 dated December 17, 2013. Administratively, Register 47 area is located in Central Lampung District, Lampung Province and covering an area is $13,749.3$ ha that previously from a) Mataram Ilir Village, Seputih Surabaya Sub-District, covering an area of 3,900 ha, from 374 land owners, b) Mataram Udik Village, Seputih Mataram Sub-District, covering an area of 3,000 ha, from 506 land owners, c) Kampung Surabaya Ilir Village, Seputih Surabaya SubDistrict, covering an area of 3,610 ha, from 366 owners, and d) the rest of the Register 47 forest area itself that has not been released.

Forest area Register 47 Way Terusan is located in the northern of 3 districts: Central Lampung, Mataram Udik, and
Bandar Mataram. The area was originally the plantation area of a company named Bumi Sari Sumber Sakti/BS3 with an area of approximately 10,510 ha for sugarcane plantations until 1985.

Starting in $1997 / 1998$, the Regional Office of the Ministry of Transmigration and Forest Encroacher Settlements, Lampung Province, relocated out 900 families of encroachers from Way Terusan of resettlement units (Satuan Pemukiman/SP) 1, SP 2, and SP 3 locations, including those from Gunung Balak area. In the relocation process, there were also resettlement units (SP) from transmigration, namely SP 3 of 300 families with an area of \pm 350 ha which overlapped in the area of the production forest area Register 47 Way Terusan. The placement of forest encroachers in this SP 3 has not received a principle permit from the Minister of Forestry, while the basis for the placement of transmigration was the Governor's Decree Number G/325/Bappeda/Hk/1996 dated July 29, 1996, regarding the reservation of the transmigration location located in Register 47. This decision was taken because it was an effort considered capable of overcoming forest damage caused by forest encroachers. This effort was made through cooperation with the private sector, namely the sugar cane plantation of PT Indo Lampung Buana Makmur, while the SP 3 placement was outside the forest area reserved for release by the Minister of Forestry.

Since 1998 the number of forest encroachers has gradually increased. The rose of encroachment made an impact on the area/land of the production forest area Register 47 Way Terusan is increasingly being occupied by encroachers coming from various regions both from Central Lampung District, outside the district, and even from outside the province.

With the increasing number of encroachers entering the forest area of Register 47 Way Terusan, on April 17, 2001, the district, together with the chairperson of the Central 
Table 1 History of Way Terusan FMU that are relevant to the forest tenure conflict

\begin{tabular}{|c|c|c|}
\hline No & Year & $\begin{array}{c}\text { Events at Way Terusan FMU that are relevant to } \\
\text { the forest tenure conflict }\end{array}$ \\
\hline 1 & 1940 & $\begin{array}{l}\text { Besluit Residen Lampung Number 249/1940, about area of production forest of Register } 47 \text { Way Terusan (Area } \\
\text { of approximately } 28,125 \mathrm{ha} \text { ) }\end{array}$ \\
\hline 2 & 1985 & $\begin{array}{l}\text { Decree of Ministry of Forestry Number 281/Kpts- } \mathrm{VII} / 1985 \text { about area of productio forest of Register } 47 \text { Way } \\
\text { Terusan. Area of } 10,510 \text { ha for forest concession company of Bumi Sumber Sari Sakti (BS3). The area is previously } \\
\text { from } 3 \text { costumery groups. }\end{array}$ \\
\hline 3 & 1986 & $\begin{array}{l}\text { Decree of Lampung Governor Number 043/Bappeda/HK/1986 about reservation of 10,510 ha as replacement of } \\
\text { production forest area of Register } 47 \text { Way Terusan. The area was or iginally from: 1) 3,900 ha from Mataram Ilir, } \\
\text { 2) 3,000 ha from Mataram Udik, and 3) 3,610 ha from Surabaya Ilir. }\end{array}$ \\
\hline 4 & 1991 & Decree of Minister of Forestry Number 67/Kpts-II/1991 about appointment of forest area in Lampung Province. \\
\hline 5 & 1994 & $\begin{array}{l}\text { Decree of Ministry of Forestry Number 1510/Menhut-VII/1994 about forest concession of 10,000 ha for Indo } \\
\text { Lampung Buana Makmur (ILBM) company. }\end{array}$ \\
\hline 6 & 1996 & $\begin{array}{l}\text { Decree of Ministry of Forestry Number 78/Kpts-II/1996 about forest concession of 16,221.04 ha for Central Pertiwi } \\
\text { Bratasena company. }\end{array}$ \\
\hline 7 & 1996 & $\begin{array}{l}\text { Decree od Ministry of Forestry Number 974/Menhut-VII/96 to release the forest concession for Indo Lampung } \\
\text { Buana Makmur (ILBM) company. In condition that the sugarcane plantation company employs ex-encroachers } \\
\text { from Register } 47 \text { area. }\end{array}$ \\
\hline 8 & 1996 & $\begin{array}{l}\text { Decree of Lampung Governor Number G/325/Bappeda/ K/96 of reserve area allocated to ex-encroachers in } \\
\text { Register } 47 .\end{array}$ \\
\hline 9 & $1997 / 1998$ & $\begin{array}{l}\text { Relocation } 900 \text { households of encroachers of Register } 47 \text { to SP } 1 \text { and SP } 2 \text { outside forest area, and SP } 3 \text { inside } \\
\text { forest area of } 350 \text { ha. This the potential tenurial conflict later. }\end{array}$ \\
\hline 10 & 2000 & $\begin{array}{l}\text { Decree of Ministry of Forestry Number 256/Menlhk-II/2000about appointment of Register 8, Way Terusan with } \\
\text { total area } 5,666.72 \text { ha }\end{array}$ \\
\hline 11 & 2001 & $\begin{array}{l}\text { Decree of Central Lampung District Number 143/Kpts/01/2001 about socialization, inventory, identification, and } \\
\text { areal management in Register } 47\end{array}$ \\
\hline 12 & 2001 & Ieeting within Central Lampung government with encroachers and represe ntatives of the villages \\
\hline 13 & 2001 & $\begin{array}{l}\text { An appeal not to carry out activities related to boundary demarcation or forest ownership that can disturb the } \\
\text { community, based on Appeal from Central Lampung District Government Number 522/1046/D.10/2001. Those } \\
\text { activities are: } \\
\text { - Costumery people's groups began to dispute their lands being transferred as replacement land to the Way Terusan } \\
\text { KPH based on a decree of Governor of Lampung Number 043/Bappeda/HK/1986 } \\
\text { - The displaced people from Gunung Balak who live in SP } 3 \text { are also starting to question the boundaries of SP3 } \\
\text { which is located in the forest } \\
\text { There are free rider parties who provoke the community about the possibility of releasing state forests into private } \\
\text { forests }\end{array}$ \\
\hline 14 & 2001 & $\begin{array}{l}\text { Carry out data collection and re-measurement in the context of structuring the production area of Register } 47 \text { Way } \\
\text { Terusan, Central Lampung District. Based on the Decree of the Head Central Lampung Forestry Bureau Number } \\
800 / 547 . \text { A/D.10/2001. There are } 63 \text { farmer groups who are members of } 7 \text { sub-villages and consist of } 6,301 \\
\text { households }\end{array}$ \\
\hline 15 & 2001 & $\begin{array}{l}\text { Meeting between the head of the district, chair of the district board member, head of district military, and head of } \\
\text { district police with the coordinators and group leaders }\end{array}$ \\
\hline 16 & $2002-2005$ & $\begin{array}{l}\text { Development of forest management groups by the Forestry Service of Central Lampung Regency, especially } \\
\text { providing an understanding of forest status to resolve tenure conflicts }\end{array}$ \\
\hline 17 & 2008 & Establishment of UPTD KPHP Register 47 Way Terusan, base d on Central Lampung's Decree Number 10/2008. \\
\hline 18 & 2009 & Re-measurement and provisional boundary Register 47 Way Terusan \\
\hline 19 & 2010 & $\begin{array}{l}\text { The definitive boundary work area of the Way Terusan consists of: } \\
\text { Register } 47 \text { production forest area of } 13,749.3 \text { ha. Definitive boundary of protected forest Register } 8 \text { area of } \\
5,666.72 \text { ha }\end{array}$ \\
\hline 20 & 2013 & $\begin{array}{l}\text { Decree of Minitry of Forestry on the determination of production forest reas on the } 47 \text { Way Terusan Register } \\
\text { Number 930/Menlhk-II/2013, covering an area of } 13,749.3 \text { ha. Then there is the preparation of the long-term forest } \\
\text { management plan (RPHJP) }\end{array}$ \\
\hline 21 & 2015 & Socialization of the forestry partnership program has begun, but it has not been fully accepted by the community \\
\hline 22 & $2016-2018$ & $\begin{array}{l}\text { Socialization of the forestry partnership program and the community began to accept the concept and then entered } \\
\text { into an agreement with the Way Terusan Management Unit. } \\
\text { In addition to the } 7 \text { sub-villages that have existed since } 2001 \text {, in } 2016 \text { there were } 3 \text { sub-villages that established the } \\
\text { faorest farmers groups. So there are } 10 \text { sub-villages that are continuously fostered so that tenure conflicts subside }\end{array}$ \\
\hline 23 & 2019 & $\begin{array}{l}\text { Approval of recognition and protection of community managed land based on the forestry partnership scheme } \\
\text { (KULIN KK) by the Ministry of Environment and Forestry for } 31 \text { forest farmers groups (on } 5 \text { sub-villages) }\end{array}$ \\
\hline
\end{tabular}


Lampung DPRD, held a meeting with the community leaders and heads of the forest area Register 47 Way Terusan cultivator groups. That meeting resulted in an agreement between the community and the representatives of the cultivators to support the Register 47 Way Terusan regulatory structuring activities that the government planned.

Based on the Central Lampung District Decree Number 143/Kits/01/2001, dated May 31, 2001 the team held socialization of the structuring program to traditional community leaders of 3 villages (Mataram Udik, Mataram Ilir, and Surabaya Ilir), along with Sub-District Heads, Police Chiefs, Military Commanders, and company representative. All those attendees agreed to strengthen the meeting results on 17 April, 2001, and support the Register 47 area arrangement activities. From August to early November 2001, data collection and measurement of forest area Register 47 Way Terusan, which the encroachers had opened was carried out.

Then on November 14, 2001 a meeting was held between the district, chairman of the DPRD, military district commander, and police chief of Central Lampung with the coordinator and heads of the Register 47 cultivator groups. The meeting resulted in the following agreements: 1) all groups (63 groups) agreed to the government's program of structuring Register 47 Way Terusan as PF CF, 2) ff the 63 groups: 33 groups joined $\mathrm{PF}$ and were ready to be partnered with third parties with facilitation by the government, 30 groups joined $\mathrm{CF}$ and managed themselves under the guidance of the district forestry and plantation service of Central Lampung.

By the end of December 2001, the District of Central Lampung issued a letter for the Head of Bandar Mataram Sub-District, regarding the processing of community forest permit requirements in Register 47 Way Terusan, according to the Minister of Forestry Decree Number 31/Kpts-II/2001, dated 12 February, 2001. Based on this event, one of the requirements to become a member of the community forest one must have an identity card (ID) of the nearest village. In connection with this, the District of Central Lampung asked the Head of the Bandar Mataram Sub-District to help smooth ID cards making and coordinate with the District Forestry and Plantation Service of Central Lampung. On January 22, 2002, the District of Central Lampung and his entourage held a working visit and at the same time announced the start of the Register 47. At the end of the visit, there was dissatisfaction with some people who had applied.

The main drivers of the conflict in Way Terusan FMU are caused by the fact the forest encroachers fight to obtain their official land ownership. The Central Lampung District Government deeply rejected the demand. Then, in 2003, some of the people who occupied Register 47 suggested converting Register 47 from forest area into property rights. The minister could not consider (rejected) this application through Letter Number 507/Menhut-VII/2003, addressed to the Lampung Provincial Forestry Service with copies to the Governor of Lampung and community representatives of the Register 47 Way Terusan. Since then, the Way Terusan FMU has never stopped having forest tenurial conflicts.
Types and development of forest tenure conflicts In FMU Way Terusan, community dependence on forest area land is very high. The Register 47 Way Terusan area also has suffered pretty severe forest damage. There are no more forest plants in this area because has already occupied by communities' settlements therefore do not support preserving the functions as a forest (Wulandari et al., 2019). The Way Terusan FMU is now resolving tenurial problems by focusing directly on the interests of the people who live in and around the forest (Ifrani et al., 2019). Until 2021, the following are tenurial problems that occur in The Way Terusan FMU: 1) the overlapping of placement areas for the SP 2 and SP 3 transmigrants located in the production forest Register 47 Way Terusan has not been resolved, 2) the overlapping of managed lands between communities who stay at inside the forest area and outsiders, 3) in some villages located inside the forest area, people still want to release the forest area into property rights, 4) indigenous peoples' claims from the customary village communities around the forest area claiming that the land belongs to them, 5) there are political promises from community leaders or political figures to assist in releasing the forest area, 6) some people from community groups and non-governmental organizations or personal individuals are interested in provoking the community to make personal benefits.

Based on the 3 main forest tenurial conflicts that occurred in Way Terusan FMU, it can be recommended for cases number 1 (initial case) and number 2 (initial case), namely accommodation and compromising with the interests of other parties and then collaborating towards the goal of sustainable forest management. Especially for case number 3 or related to the issue of customary forest claims, it seems that the community is still in an evasive position.

Conflict facilitating parties with compromise and accommodation styles Based on identified problems resulting in conflicts in the research area, the Way Terusan FMU first needs to assess and determine the roots of the problems so that the conflict resolution method adopted is effective. The first approach is the compromise-style party (Huan \& Yazdanifard, 2012). The second approach is accommodating (Huan \& Yazdanifard, 2012). Based on the results of observations in the grass-root research field, tenurial conflicts can be resolved by facilitating parties in compromise and accommodation styles.

1) Related to the unresolved overlapping of areas for the placement of SP 2 and SP 3 transmigrants who are in the area of Register 47 Production forest SP 2 is an area where community settlements are outside the forest area, but the management area is in the forest area. In contrast, SP 3 is an area where the settlements and land under management are in the forest. The SP 2 and SP 3 transmigration communities currently occupy a portion of the area (around $350 \mathrm{ha}$ ) of the Register 47 plantation forest, meaning that there is an overlap within the use of the forest area and the agency that administers transmigration. In this matter, the Way Terusan FMU has opened the communication room. There is also a swap scheme (relocation and replacing the area inside forest area to other area outside the forest area) in accordance with 
the mandate in the Decree of the Minister of Forestry Number 930/2013 concerning the Determination of the Register 47 forest area. The reference of a resolution mechanism will follow the applicable laws and regulations.

During the last four years, the forest management unit, as the manager in the field, has provided the communication room and coordination for the transmigration management to resolve the problem jointly. By the end of 2021 it is expected that there will be a common ground regarding the resolution of the above problem. It means that the FMU implements compromise as an initial step in resolving the occurring conflicts. Based on the interview, Way Terusan FMU will not allow this problem to drag on or continue to wait for the transmigration management to implement the swap program in the area used by the SP 2 and SP 3 communities.

According to FMU staff, there are a forest function that is not optimal due to the existence of settlements. Actually, all of the SP 3 people have acknowledged that their state owns their area since four years ago. The Ministry of Transmigration has planned to move transmigrants or "swap" so that they can be outside the forest, both their forest management areas and settlements. This program is still ongoing, but unfortunately, it is not yet completed due to constraints in the boundary delineation process, an inventory of forest resources that have not been carried out, and financing. Having the authority, the FMU has an alternative solution to the overlapping SP 2 and SP 3 land issues. The alternative is the accommodation of SP 2 and SP 3 transmigration communities who manage lands in the Way Terusan production forest area to be involved in the social forestry program to have legal permits to manage forests for 35 years. The accommodation resolution style is used by the FMU so that people immediately have a legal umbrella in managing forest areas.

2) Conflicts occur in some villages that have not participated in government programs People still want the government to release the forest area where they live to become their property. The FMU carries out conflict resolution in a compromising manner. Particularly in resolving tenurial problems, the FMU takes a persuasive approach to the communities through socialization, guidance, and law enforcement programs (Sahide et al., 2015). These programs are carried out directly by the FMU. All FMU staff are actively involved and live in the field. In its operations, the FMU will take the next conflict resolution step, namely accommodation. This accommodation step can be seen when the FMU involves active community participation. In fact, the community members involved are members of the villages in conflict with the FMU because they still want to own the forest areas they live in. They have been invited to join the PKSM (community forestry extension agents) and the Pamhut Brigade (forest security). The facilitation of various training and capacity building in maintaining the security of the forest area and villages for about three years has made them members of PKSM and Pamhut Brigade with high awareness to maintain security and also understand the forest area status. It is expected that the community members of the PKSM and the Pamhut Brigade, having a correct understanding of the state forest status, will pass by word of mouth to other community members so that this tenurial conflict will continue to decrease.

Conflict resolution facilitation for avoidance parties style 1) There are indigenous people from customary communities around the forest area claiming that the 3,000 ha land belongs to their custom. The surrounding customary villages are Kampung Surabaya Ilir, Mataram Udik, and Mataram Ilir. These communities have committed various actions that are contradictory with legal law, namely: 1) claiming the area of customary land, 2) managing the land that overlaps with the land of the surrounding village communities, and 3) encroaching into areas that they claim as customary land. Due to the avoidance style adopted by the local customary people, the FMU intensively provides socialization of the forest status to them as they continue to claim their customary land. In addition, the FMU also opens up opportunities for proving through legal channels if they ask for it. The FMU takes legal action as a form of protection for some people who have obtained the legality of utilizing forest areas, for example through the SF scheme. With this step, it is expected that those who obey the law by becoming members of the SF will be protected in carrying out various forest utilization programs covered in the permit certificates. Furthermore, it is necessary to assist those who have obtained legality.Therefore. appropriate assistance will manage their forest areas legally and peacefully (Wulandari \& Kurniasih, 2019). Currently, the FMU has provided assistance by living in the field to capture all community dynamics that occur in the Register 47 Area FMU.

2) There is a political promise from community or political figures to help release the forest area Those individuals will usually stay away from when the FMU asks people to bring them to sit together with the FMU. It is the duty of the FMU as the forest area manager to know the intentions of this political promise so that people are not deceived and able to judge whether the promise will be fulfilled or not. The objective of this is to anticipate the negative impact of these individuals on forest farmer groups.

The FMU has a policy of having an assistant living in the field for the groups that have obtained legal permits (Wulandari et al., 2016). The assistant is in charge of providing new training and knowledge related to regulations or other matters aimed at increasing the human resources capacity of members of the forest farmer groups (Saipurrozi et al., 2018; Wulandari \& Kurniasih, 2019).

3) Overlapping of cultivated lands managed by the communities inside and outside the forest area due to the existence of individuals or village coordinators playing the buying and selling cultivated lands in the forest area Based on the field research findings, even though those individuals will always try to avoid, in resolving this tenurial conflict, the FMU will put both parties to sit together, then together with the FMU, to discuss the basis of the claims of the cultivated lands and their real conditions in the field. Next, the FMU will take steps and make a decision referring to the laws and regulations. The Register 47 Way Terusan is a state forest area in which there is no definitive government 
administration, the FMU clearly does not recognize the existence of government administration in the forest area. In this case, however, the FMU respects the existing village coordinators as a liaison for the communities in the area. People have been made aware that village coordinators do not have the authority to change the status or buy and sell the forest areas. So this is certainly useful for other communities who may not have the opportunity to meet or talk to get information from the FMU. Based on this condition, it still takes quite a long time for the people in case number 3 to be invited to compromise.

Conflict resolution facilitation for competition parties style Based on the field research found, there are also individuals in the community from community groups, nongovernmental organizations, or personal individuals who are interested in provoking people to make personal benefits. It means that the Way Terusan FMU also faces competitionstyle tenurial conflicts. In this regard, the FMU has begun to tighten its control function over the existence of these individuals and take legal action if necessary. So far, the FMU has been very selective in choosing its partners, either from NGOs or other community groups. Before the FMU partners enter the community, the FMU asks them to make presentations of their aims and objectives to know whether these aims and objectives are in line with the vision and mission of the FMU or the presence of those partners is actually detrimental to all parties, either the FMU or the community. In anticipation of this, the FMU has formed an investigation team consisting of members of the forestry extension officers and the police at the FMU.

It can be seen that one of the important points based on the resolution of tenurial conflicts in the field as the priority in resolving forest tenurial conflicts in the register 47 Way Terusan is that the FMU continues to strive to be able to act and make the right decisions. It means that the decisions are in accordance with the management plan in the working area as well as the authorities mandated by the laws and regulations (Carvalho et al., 2019). Among others, a program being carried out by the FMU in order to resolve all conflicts on Register 47 is to invite the community to play an active role in implementing forestry partnership cooperation programs with the FMU. The existence of a partnership with the community in all programs of resolving conflicts will certainly ensure their success (Elva et al., 2017; Wandira et al., 2020). In addition, it also increases mutual respect for the roles and responsibilities between the FMU and the community in maintaining security and managing forests towards SFM (Setiawan et al., 2018).

\section{Conclusion}

In conclusion, the forest area of Way Terusan FMU is the area where the conflict of land is still taking place, especially with the claim of households over the land ownership of the forest area. The encroachment began when the relocation under the Ministry of Transmigration, but without the Ministry of Forestry's accord. Various legalization permits have been applied to the central government, but it was not considered a solution. The FMU is the principal actor in forest management since the regional regulation of forest area law's implementation in 2019 could implement forest community partnership scenarios through grassroot approach or stays in conflict location and succeeded. Parties in compromise and accommodation styles can help to resolve tenurial disagreements.

\section{Recommendation}

This research suggests considering compromise and accommodation styles to resolve the tenurial conflicts in Way Terusan FMU area. Furthermore, an advanced study is needed to observe possible scenarios in collaborating with the community in forest community partnership schemes based on the typology of encroachment and conflict nature.

\section{References}

Carvalho, W. D., Mustin, K., Hilario, R. R., Vasconcelos' I. M., Eilers, V., \& Fearnside, P. M. (2019). Deforestation control in the Brazilian Amazon: A conservation struggle being lost as agreements and regulations are sub verted and by passed. Perspective in Ecology and Conservation, 17, 122-130. https://doi.org/10.1016/ j.pecon.2019.06.002

Elva, Kaskoyo, H., Febryano, I. G., \& Yuwono, S. B. (2017). Kajian kelembagaan gabungan kelompok tani dalam program kemitraan di KPHP Way Terusan. Jurnal Hutan Tropis, 5(1), 1-7.

[FAO] Food and Agriculture Organization. (2019). Assessing the governance of tenure for improving forests and livelihoods-A tool to support the implementation of the voluntary guidelines on the responsible governance of tenure. Forestry Working Paper No. 13.

Galudra, G., Sirait, M., Pasya, G., Fay, C., Suyanto, Van Noordwijk, M., Mvan., \& Pradhan, U. (2010). RaTA: A rapid land tenure assessment manual for identifying the nature of land tenure conflicts. Bogor: World Agroforestry Centre.

Galudra, G., Van Noordwijk. M., Agung, P., Suyanto, S., \& Pradhan, U. (2014). Migrants, land markets and carbon emissions in Jambi, Indonesia: Land tenure change and the prospect of emission reduction. Mitigation and Adaptation Strategies for Global Change, 19(6), 715-731.

Galudra, G., Pradhan, U. P., \& Sirait, M. T. (2020). Rapid land tenure assessment (RaTA): Understanding land tenure conflicts. World, 7 .

Gamin, Nugroho, B., Kartodihardjo, H., Kolopaking, L. M., \& Boer, R. (2014). Menyelesaikan konflik penguasaan kawasan hutan melalui pendekatan gaya sengketa para pihak di Kesatuan Pengelolaan Hutan Lakitan. Jurnal Analisis Kebijakan Kehutanan, 11(1), 71-90.

Gebara, M. M. (2018). Tenure reforms in indigenous lands: decentralized forest management or illegalism? Current Opinion in Environmental Sustainability, 32, 60-67. https://doi.org/10.1016/j.cosust.2018.04.008 
Handoko, C. (2014). Some problems in maintaining sustainability of Indonesia's forests: Descriptive study. Indonesian Journal of Forestry Research, 1(1), 33-46.

Huan, L. J. \& Yazdanifard, R. (2012). The difference of conflict management styles and conflict resolution in workplace. Business \& Entrepreneurship Journal, 1(1), 141-155.

Jenke, M., \& Pretzsch, J. (2021). The impact of community forest formalisation on tenure security and comanagement in Thailand. The International Forestry Review, 23(1), 29-40. https://doi.org/10.1505/146554 821832140321

Jun, H., Cao, Y., Erbaugh, J. T., Widagdo, F. R. A., Mauri, J., Supriyanto, \& Milantara, N. (2020). Three generations of forest peoples' empowerment in Indonesia: Process towards sustainable and equitable forest management. Jurnal Manajemen Hutan Tropika, 26(2), 91-104. https://doi.org/10.7226/jtfm.26.2.91

Ifrani, Abby, F. A., Barkatullah, A. H., Nurhayati, Y., \& Said M. Y. (2019). Forest management based on local culture of Dayak Kotabaru in the perspective of customary law for a sustainable future and prosperity of the local community. MDPI, 8(2), 78. https://doi.org/10.3390/ resources 8020078

Katila, P., McDermott, C., Larson, A., Aggarwal, S., \& Giessen, L. (2020). Forest tenure and the sustainable development goals-A critical view. Forest Policy and Economics, 120, 102294. https://doi.org/10.1016/ j.forpol.2020.102294

Kim, Y.-S., Bae, J. S., Fisher, L. A., Latifah, S., Afifi, M., Lee, S. M., \& Kim, I.-A. (2016). Indonesia's forest management units: Effective intermediaries in REDD+ implementation? Forest Policy and Economics, 62, 69-77.https://doi.org/10.1016/j.forpol.2015.09.004

Larson, A. M. (2013). Hak tenurial dan akses ke hutan: Manual pelatihan untuk penelitian. Bogor: CIFOR. Retrieved from https://www.cifor.org/publications/ pdf_files/Books/BLarson1302.pdf

McLain, R., Lawry, S., Guariguata, M. R., \& Reed, J. (2021). Toward a tenure-responsive approach to forest landscape restoration: A proposed tenure diagnostic for assessing restoration opportunities. Land Use Policy, 104, 103748. https://doi.org/10.1016/j.landusepol.2018.11.053

Massiri, S. D., Malik, A., Golar, G., Hamzari, H., \& Nugroho, B. (2020). Institutional capacity of forest management unit in promoting sustainable community-based forest management. Case study of forest management unit in Central Sulawesi Province, Indonesia. Jurnal Manajemen Hutan Tropika, 26(2), 169-177. https://doi.org/10.7226/ jtfm.26.2.169

[MoEF] Ministry of Environment and Forestry. (2021). Jumlah penanganan pengaduan. Retrieved from: http://pskl.menlhk.go.id/pktha/pengaduan/frontend/web /index.php?r=site\%2Fjumlah-penanganan-pengaduan

Pasya, G., \& Sirait, M. T. (2011). Analisa gaya bersengketaAGATA. Panduan ringkas untuk membantu memilih bentuk penyelesaian sengketa pengelolaan sumberdaya alam. Bogor: Samdhana Institute.

Purnomo, E. P. \& Anand P. B. (2014). The conflict of forest tenure and the emergence of community based forest management in Indonesia. Journal of Gouverment and Politics, 5(1), 20-31. https://doi.org/10.18196/jgp.2014. 0003

Sahide, M. A. K., Micah, R. F., Maryudi, A., Dhiaulhaq, A., Wulandari, C., Kim, Y. S., \& Giessen, L. (2018). Deadlock opportunism in contesting conservation areas in Indonesia. Land Use Policy, 17, 412-424. https://doi.org/10.1016/j.landusepol. 2018.05.020

Saipurrozi, M., Febryano, I. G., \& Kaskoyo, H. (2018). Uji coba program kemitraan kehutanan di Kesatuan Pengelolaan Hutan Unit XIV Gedong Wani, Provinsi Lampung. Jurnal Hutan Tropis, 6(1), 35-42.

Schürmann, A., Kleemann, J., Fürst, C., \& Teucher, M. (2020). Assessing the relationship between land tenure issues and land cover changes around the Arabuko Sokoke Forest in Kenya. Land Use Policy, 95, 104625. https://doi.org/10.1016/j.landusepol.2020.104625

Senoaji, G., Hidayat, M. F., \& Iskandar. (2019). Resolusi konflik tenurial pemanfaatan kawasan hutan di hutan lindung Rimbo Donok Kabupaten Kepahiyang. Jurnal Manusia dan Lingkungan, 26(1), 283 https://doi.org/ 10.22146/jml.29250

Setiawan, R., Febryano, I. G., \& Bintoro, A. (2018). Partisipasi masyarakat pada pengembangan agroforestri dalam program kemitraan di KPH Unit XIV Gedong Wani. Junal Sylva Lestari, 6(3), 56-63. http://doi.org/10.23960/js13656-63

Simmons, B. A., Marcos-Martinez, R., Law, E. A., Bryan, B. A., \& Wilson, K. A. (2018). Frequent policy uncertainty can negate the benefits of forest conservation policy. Environmental Science \& Policy, 89, 401-411.

Stickler, M. M., Huntington, H., Haflett, A., Petrova, S. \& Bouvier, I. (2017). Does de facto forest tenure affect forest condition? Community perceptions from Zambia. Forest Policy and Economics, 85, 32-45. https://doi.org/ 10.1016/j.forpol.2017.08.014

Sugiono. (2012). Understanding of qualitative research. Bandung: Alfabeta.

Syaifullah, Z. A., \& Sarjono. (2012). Laporan asesmen dan analisa tenurial untuk mendukung fungsionalisasi KPHP Register 47 Way Terusan di Kabupaten Lampung Tengah Propinsi Lampung. Jakarta: WG Tenure, Kemitraan, ICCO Kementerian Kehutanan. 
Sylviani, S., \& Hakim, I. (2014). Analisis tenurial dalam pengembangan kesatuan pengelolaan hutan $(\mathrm{KPH})$ : Studi kasus KPH Gedong Wani, Provinsi Lampung. Jurnal Penelitian Sosial dan Ekonomi Kehutanan, 11(4), 309-322.

Tjoa, M., Suharjito, D., Kartodiharjo, H. \& Soetarto, E. (2018). Hak penguasaan lahan hutan pada masyarakat adat di Desa Honitetu Kabupaten Seram Bagian Barat, Maluku. Jurnal Sylva Lestari, 6(3), 91-102. https://doi.org/10.23960/js13691-102

van Aken, J. E. (2004). Management research based on the paradigm of the design sciences: The quest for field-tested and grounded technological rules. Journal of Management Studies, 41(2), 219-246. https://doi.org/ 10.1111/j.1467-6486.2004.00430.x

Wandira, A., Kaskoyo, H., Febryano, I.G. \& Yuwono,S.B. (2020). Implementasi kemitraan kehutanan di Kesatuan Pengelolaan Hutan Produksi Way Terusan. Jurnal Hutan Tropis, 8(3), 244-250.

Wario, R. A., Ton, D., Karen, W., \& Fred, Z. (2012). Climate change, violent conflict and local institutions in Kenya's drylands. Journal of Peace Research, 49(1), 65-80. https://doi.org/10.1177/0022343311427344

Wilson, V. (2014). Research methods: Triangulation. Evidence Based Library and Information Practice, 9(1), 74-75. https://doi.org/10.18438/B8WW3X

Working Group Tenure. (2012). Resolusi konflik di FMU (Pembelajaran dari FMU Register 47 dan Rinjani Barat). Jakarta: WG Tenure, Kemitraan and Ministry of Forestry.
Wulandari, C., Budiono, P., \& Nurrochmat, D. R. (2016). Kesiapan daerah dalam implementasikan program perhutanan sosial pasca terbitnya UU 23/2014 tentang pemerintahan daerah. Risalah Kebijakan Pertanian dan Lingkungan, 3(2), 108-117. https://doi.org/10.20957/ jkebijakan.v3i2.15512

Wulandari, C. \& Kurniasih, H. (2019) Community preferences for social forestry facilitation programming in Lampung, Indonesia. Journal of Forestry and Society, 3(1),114-132. https://doi.org/10.24259/fs.v3i1.6026

Wulandari, C., Landicho, L. M., Cabahug, R. E. D., Baliton, R. S., Banuwa, I. S., Herwanti, S, \& Budiono, P. (2019). Food security status in agroforestry landscapes of Way Betung Watershed, Indonesia and Molawin Dampalit Subwatershed, Philippines. Jurnal Manajemen Hutan Tropika, 25(3), 164-172. https://doi.org/10.7226/ jtfm.25.3.164

Tashakkori, A., Johnson, B., \& Teddlie, C. (2021). Foundations of mixed methods research: Integrating quantitative and qualitative approaches in the social and behavioral sciences (2nd ed.). Thousand Oaks, California: SAGE Publications, Inc.

Yin, R. K. 2014. Case study research: Design and methods (5th ed.). Los Angeles: SAGE.

Yiwen, Z., Kant, S., Dong, J. \& Liu, J. (2020). How communities restructured forest tenure throughout the top-down devolution reform: Using the case of Fujian, China. Forest Policy and Economics, 119, 102-272. https://doi.org/10.1016/j.forpol.2020.102272

Zaini, Z. D. (2011). Implementasi pendekatan yuridis normatif dan pendekatan normatif sosiologis dalam penelitian ilmu hukum. Pranata Hukum, 6(2), 117-132. 